\title{
RELAÇÕES SOCIAIS NO TRABALHO E SUBJETIVIDADE DO TRABALHADOR
}

\author{
Liliana Rolfsen Petrilli Segnini \\ Professora titular do Departamento de Ciências Sociais da Faculdade de Educação da Unicamp. \\ E-mail: lilianaseg@uol.com.br
}

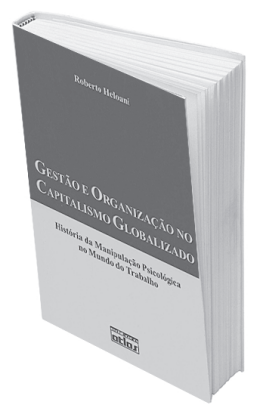

GESTÃO E ORGANIZAÇÃO NO CAPITALISMO

GLOBALIZADO: HISTÓRIA DA MANIPULAÇÃO

PSICOLÓGICA NO MUNDO DO TRABALHO

De Roberto Heloani

São Paulo: Atlas, 2003. 240 p.
O trabalho é o tema central desse livro. A obra trata, mais precisamente, das implicações psicológicas na construção da subjetividade do trabalhador nas relações de trabalho.

O trabalho pode ser visto pelo menos sob duas perspectivas. A primeira se refere à relação, observável em qualquer momento histórico, entre o homem e a natureza, transformando-a em algo útil. A ação humana de transformar a natureza para seu próprio proveito implica também na transformação do próprio homem. Tal condição se reconfigura em vários momentos históricos, que se diferenciam, e constitui a segunda perspectiva: a relação social entre os homens. Exemplos que informam esses diferentes períodos são observados nas diferentes formas de organização do trabalho nos contextos feudal, escravocrata e assalariado.
José Roberto Montes Heloani analisa a organização e as relações de trabalho em um longo período histórico no capitalismo, desde o final do século XIX, quando o nascimento da indústria moderna levou a condições sociais favoráveis para a expansão do capital monopolista e à expansão do assalariamento. Essa forma de relação de trabalho social e historicamente determinada encerra duas dimensões, tencionadas política e socialmente. Por um lado, o trabalho, objetivado, passível de descrição em seqüências observáveis e mensuráveis; por outro, o trabalhador, que em condições sociais determinadas produz mercadorias, na relação que estabelece com o trabalho objetivo, sob o controle do capital.

A história do trabalho assalariado é marcada pelas tensões entre as formas de poder e de controle, e a re- sistência nas relações entre os elementos objetivos do trabalho - os meios de produção - e os elementos subjetivos do trabalho - a força de trabalho. Heloani analisa essa história e a circunscreve em seus contextos históricos específicos, inscrevendo a subjetividade do trabalhador como elemento fundamental na sua construção.

Para tanto, recorre a metáforas habilmente elaboradas por meio de títulos de filmes, informando ao leitor que as singularidades das formas de manipulação da subjetividade do trabalhador, em diferentes períodos no contexto do assalariamento, traz uma universalidade (o "eterno regresso") em termos de processos de trabalho. Tais processos, mais do que controlar tempos e movimentos (por meio dos princípios associados ao taylorismo), procuram influir naqui- 
lo que é inerente à condição humana, que a distingue da de outros seres vivos na natureza: sua própria capacidade de perceber o mundo, sua própria subjetividade.

Em qualquer período histórico considerado, as relações sociais estabelecidas na esfera do trabalho são produtoras de vivências. Com isso, as condições objetivas de trabalho contribuem para o desenvolvimento de subjetividades; o trabalho extrapola os aspectos que o normatizam e os aspectos legais que o regulamentam. Tal movimento, de dinâmica complexa, estabelece relações de pertencimento a coletivos de trabalho, os quais contribuem para a elaboração da subjetividade de homens e mulheres. Essa hipótese é trabalhada por Heloani, que busca "desconstruir" as relações de trabalho desde a introdução do taylorismo, inclusive o soviético (stakhanovismo).

Nos países industrializados a expansão do fordismo como forma de regulação possibilitou que a produção em massa fosse articulada ao consumo de massa, mediada por acordos políticos entre o Estado, o capital e os sindicatos. Em dado momento histórico, a expansão dos direitos vinculados ao trabalho e o acesso ao consumo tiveram por base a proposta centrada na cooperação entre as classes. De acordo com Heloani, trata-se de "tempos modernos", nos quais foram estabelecidas "ligações perigosas", sendo a ciência incorporada como "utopia redentora".

O modelo fordista pode ser visto como um projeto inconcluso de regulação social. A utopia de uma sociedade mais justa, na qual todos os trabalhadores seriam consumidores, com direitos vinculados ao trabalho, não se sustentou na perspectiva da divisão internacional do trabalho, no interior da qual as desigualdades se tornaram flagrantes. Mesmo considerando somente os países que lograram êxito na implementação do fordismo, observa-se que nem toda a população foi privilegiada. A lógica excludente se manifestou na divisão racial e sexual do trabalho.

Assim, os países pobres não foram privilegiados de forma simétrica se comparados com países ricos, e as distâncias econômicas e sociais se aprofundaram. Em qualquer desses países, a assimetria é observada entre os homens brancos em relação aos homens negros e imigrantes, e em relação às mulheres. Portanto, mesmo no interior da classe trabalhadora ocorreram desigualdades, com implicações para a subjetividade dos indivíduos.

A análise histórica da construção social do indivíduo e de sua subjetividade mostra também o agravamento da crise do fordismo na década de 1970 e o crescimento do "ovo da serpente": a consolidação da regulação denominada "flexível" e a expansão do neoliberalismo, bem representadas pelas formas japonesas de organização do trabalho, como o toyotismo, o sistema just-in-time e os círculos de controles de qualidade. Tais sistemas trazem o "eterno regresso" dos controles neotaylorizados e atentam cada vez mais para as formas de relação individual com o trabalhador, dificultando a construção de formas coletivizadas de relação, o que impede o desenvolvimento de maneira equilibrada das relações no mundo do trabalho.

Gradativamente, a individualização do trabalhador se tornou a principal estratégia de manipulação de subjetividades; primeiro, em contextos caracterizados pela intensificação do trabalho, para os que permanecem empregados; segundo, de perda de proteção do trabalho e do trabalhador, para aqueles que estão à de- riva, trabalhando por múltiplas formas de contratos de curta duração; e terceiro, sobretudo, pelo crescente desemprego observado a partir da década de 1980. Esses fenômenos recentes provocam medo e desamparo nos trabalhadores, desestruturando suas referências e sua identidade, e levando à corrosão do caráter, como observou Richard Sennet.

Heloani amplia sua análise ao incorporar referências orientais e ocidentais à discussão dos diferentes momentos históricos tratados, vivenciados no âmbito do sistema capitalista, reafirmando a longa vida do taylorismo e de suas novas configurações, presentes nas formas aparentemente participativas de gestão. No entanto, o autor previne o leitor, observando que "[...] a lógica dialética nos ensina que toda dominação é processual, portanto transformadora e transformada, e passível de resistência e conflito". Assim, não se completa jamais, apenas existe enquanto processo.

Em tempos que a retórica da flexibilização se torna onipresente, esta obra interessa sem dúvida aos estudiosos e atentos ao debate sobre a essencialidade do trabalho, tanto no plano individual como no social. Interessa do mesmo modo àqueles que vivenciam as relações de trabalho, que se percebem partícipes de uma história que busca a consolidação dos direitos civis e sociais, com a conseqüente consolidação dos direitos trabalhistas, de modo a garantir que o ser humano, enquanto na condição de "ser que produz para os outros", seja o menos violentado possível em sua subjetividade. O texto flui agradavelmente, mesmo sendo uma adaptação de um trabalho acadêmico na sua origem - tese de livre docência defendido pelo autor na Universidade Estadual de Campinas, avaliado com nota máxima. 